\title{
Policy Support for and Barriers to Transit-Oriented Development in the Inner City Literature Review
}

\author{
Daniel Baldwin Hess and Peter A. Lombardi
}

The promise of transit-oriented development (TOD) for increasing transit ridership, enhancing economic development, and establishing a "sense of place" at transportation nodes has been well documented in the literature. However, the majority of research addresses TOD in greenfield sites located primarily in suburban places in growing regions. The policies that are widely believed to be supportive of TOD are examined, the gap in knowledge about TOD in established city neighborhoods is addressed, and the challenges of TOD in different urban settings are compared. Findings reveal that $(a)$ the literature appears to be consistent and confident in outlining the public policies that encourage TOD; (b) researchers tend to focus on TODs in suburban and greenfield areas of fast-growing regions in the western and southern United States; (c) TODs in older cities are not well publicized and are largely ignored by the literature; and $(d)$ researchers who study inner-city TOD usually focus on the lack of it, or any type of development, in economically depressed areas. The conclusion of several researchers that a strong local economy is key to successful TOD offers a clue as to why recently built TOD is largely absent from many older, slow-growth cities like Buffalo, New York, and St. Louis, Missouri. It also offers some insight into why the TOD trend is strongest in high-growth metropolitan areas like San Diego, California, and why it seems to skip struggling neighborhoods within them, like South Central Los Angeles, California. Although pre1950s TOD is common in older cities, that ubiquity appears to reduce the publicity and attention given to more recent TOD in those places.

Over the past several decades, American cities from Buffalo, New York, to San Diego, California, have invested billions of dollars in modern rail-based rapid transit systems (1-4). In every case, the goals of traffic relief and improved air quality were accompanied by an expectation of economic development around new transit stations (5). The type of development foreseen, for the most part, was the dense transit- and pedestrian-friendly variety that occurred so naturally along the streetcar lines of early 20th-century America (6, 7).

Many of these places, however, have found transit-oriented development (TOD) to be exceedingly unnatural today. After 50 or more years of focusing on the accommodation of automobiles, even cities with countless examples of transit-oriented streets and neighborhoods from the early 1900 s have been unable to encourage such develop-

Department of Urban and Regional Planning, University at Buffalo, State University of New York, 3435 Main Street, 116 Hayes Hall, Buffalo, NY 14214-3087.

Transportation Research Record: Journal of the Transportation Research Board, No. 1887, TRB, National Research Council, Washington, D.C., 2004, pp. 26-33. ment in the 21st century. In many cities, the suburbs flourish at the expense of transit- and pedestrian-friendly neighborhoods in the city, which are often losing population and experiencing little new development. Consequently, inner-city locations in older urban areas pose specific challenges for TOD that do not necessarily arise when TOD is planned for or established in new suburban or greenfield sites.

This study is motivated by a desire to understand the effects of public policy and location on TOD as well as the particular constraints and opportunities of TOD in inner-city areas. The study draws on literature in the urban planning, urban design, and transportation planning disciplines, focusing on research published in studies, reports, and scholarly journals. The goal is to address the gap in knowledge about TOD in established city neighborhoods and compare the challenges of TOD in different urban settings.

\section{TRANSIT-ORIENTED DEVELOPMENT DEFINED}

TOD has received a great deal of attention in the urban planning and transportation literature, and most TOD definitions differ little from the one offered by Peter Calthorpe, a leader in the New Urbanism movement. In The Next American Metropolis, Calthorpe describes TOD as "a mixed-use community within an average 2,000-foot (or 10-minute) walking distance of a transit stop and core commercial area. TODs mix residential, retail, office, open space, and public uses in a walkable environment, making it convenient for residents and employees to travel by transit, bicycle, foot, or car" (8). To encourage development at the appropriate scale, Calthorpe differentiates between urban TODs (located directly on rail transit lines) and neighborhood TODs (located along local bus lines that feed directly into rail transit lines). He describes urban TODs as denser and more focused on employment clustering than are neighborhood TODs, which tend to emphasize housing. Both types of TOD that Calthorpe describes are aimed primarily at urbanizing suburban developments.

For TODs incorporating housing, the residential density usually considered adequate for an urban site is a minimum average of 15 units per acre (8). This figure is significantly higher than today's typical suburban developments of 4 to 5 units per acre and close to the density of streetcar suburbs of the early 20th century $(7,9)$. Bernick and Cervero prescribe 15 housing units per acre with mixtures of small-lot single-family homes and duplexes or triplexes (10). They argue that Hong Kong-like densities are hardly necessary to sustain mass transit; however, increasing the density of housing near transit stations clearly is one way of urbanizing places and increasing the demand for transit. 


\section{Terminology}

The term transit village is often used to describe TOD. For the most part, the concept of a transit village is no different from that of TOD. What Cervero and other users of the term appear to emphasize is the idea of a true community centered on a transit station (11-13). Belzer and Autler (14), in stressing this concept of community, note that TOD, "unlike other forms of development, should explicitly perform a dual function as both a node within a larger regional or metropolitan system and a good place in its own right." Transit villages, then, can establish a sense of community through their physical features (by adding new indoor or outdoor public spaces), public amenities (by including seating, trees, parks, and plazas), and social function (by including community services).

Another term that often surfaces in the TOD literature is transit joint development (TJD), which refers specifically to development that occurs at, above, below, or adjacent to a transit facility on property controlled by the transit agency (whereas TOD refers to any development that occurs - on land owned by the transit system or others-in the general vicinity of a station). According to Cervero et al., who devote an entire manual to the subject (15), TJD is based on the idea of a quid pro quo. Private developers benefit from higher occupancy rates and sales volumes due to their location at or directly adjacent to a station, and transit agencies benefit from increased ridership and a stream of lease income (16). This approach to TOD is undertaken by the Los Angeles Metropolitan Transportation Authority as well as transit agencies in other large cities that perform land use planning and engage in joint development in addition to their missions to provide public transportation (17).

\section{Benefits}

Many researchers agree on the benefits that can accrue from TOD, transit villages, and TJD. A California Department of Transportation study (18) summarizes the benefits of TOD for California:

- Provides mobility choices,

- Increases public safety,

- Increases transit ridership,

- Reduces rates of vehicle miles traveled,

- Increases households' disposable income,

- Reduces air pollution and energy consumption rates,

- Helps conserve resource lands and open space,

- Plays a role in economic development,

- Decreases infrastructure costs, and

- Contributes to more affordable housing.

Some researchers, including Newman and Kenworthy (19), conclude that TOD has great potential for reducing automobile use, increasing transit ridership, and fostering a sense of community in neighborhoods. Other researchers, such as Boarnet and Compin (20) and Giuliano (21) are less convinced that mixed land uses in proximity to transit stations have the potential to significantly influence the form of development, people's travel behavior, or people's mode choice (22). For example, in a case study of TOD in Portland, Oregon, Bae concludes that, because of development complications, much of the development at the Orenco light rail station is too distant from the transit facilities to make it convenient for users (23). Research has also specifically focused on the relationship between rail service and commercial land values (24) and the relationship between transit and housing markets (25). In general, such research suggests that singular measures, such as transit-based housing or transit-adjacent employment centers, are not influential enough in isolation; instead, TOD is more effective when it includes a mixture of uses and is supported by a web of supportive policies.

\section{PUBLIC POLICY AND TRANSIT-ORIENTED DEVELOPMENT}

The success of TOD is driven in large part by the public policies that encourage this unique type of development. The literature concerning policy and TOD can be subdivided into three key topics:

- Zoning and design codes in specific cities,

- General roles of local governments and transit agencies with regard to TOD, and

- Factors, influenced by policy, that contribute to successful TOD.

\section{Case Studies}

The TOD literature often focuses on case studies-certain cities' experiences with TOD (26). Quite a few have been written about San Diego. For example, Bragado examines the TOD policies of San Diego's transit agency (one of which is an agreement that the city provide a senior planner to work as a full-time liaison to the agency) and of the city itself (27). The city of San Diego mandates that copies of any site plan requiring a discretionary permit from the city be sent to the transit agency for review, thus allowing the agency to influence the project's design and request rights-of-way for transit facilities. The city also requires that commercial and residential developments in the vicinity of transit stations provide bicycle parking spaces. San Diego's TOD design guidelines specifically address streets and circulation, transit stop location and design, parking supply, pedestrian and bicycle pathways, and redevelopment strategies (8).

TOD in San Diego-along with new developments in Los Angeles, Sacramento, and San Francisco-is also extensively reviewed by Cervero in Transit Villages in California (28). Cervero, who has perhaps written more about TOD than any other researcher, goes on to describe and suggest financial assistance mechanisms to encourage TOD throughout that state, such as income tax credits for those who build in designated station-areas, tax abatements to underwrite the cost of development, the waiver of local development impact fees, and the strategic use of Enterprise Zones and related programs to encourage TOD (29).

Other researchers examining policies in individual metropolitan areas include Babsin et al. (30), White and McDaniel (31), and Porter (3), the latter providing descriptions of transit systems, policy frameworks, obstacles, and opportunities for TOD in 18 North American cities. In an analysis of obstacles and opportunities, Porter describes the extent to which each city is committed to making TOD work (3). The commitment is strong in cities where transit agencies and local governments work to coordinate TOD-supportive policies but weak in cities where interagency communication is minimal or combative.

For cities committed to the idea of mixed-use, pedestrian-friendly development, a TOD planning template is available in the American Planning Association's Growing Smart Legislative Guidebook (32). This model outlines the necessary components of a TOD plan, 
which include supportive studies (analyses of parking, land use, and market conditions), a statement of goals (encouraging mixed uses and enhancing pedestrian circulation), and a list of actions to be taken (amending development regulations and assigning specific roles to individual agencies).

\section{Implementation: Key Players and Roles}

A few researchers focus on the roles of the players in the development process. Renne and Newman describe the distinct roles of the public and private sectors during the three stages of joint development: planning, development, and build-out. During the planning stage, for example, the public sector should set goals, develop a community vision in coordination with the public, seek out suitable development partners, create legal agreements between all parties, analyze feasibility, and develop exit strategies (33). Meanwhile, the private sector should establish its own goals, create a business plan for accomplishing those goals, and develop exit strategies. These exit strategies are particularly important, because they set the stage for the private market's (instead of the public sector's) eventual control of commercial and retail enterprises.

Cervero focuses on the roles and tools of three particular divisions of the public sector: redevelopment agencies, transit agencies, and local governments (28). Transit agencies can promote TOD through many means, for example, by using agency-held land, underwriting land costs, assisting in land assembly, providing financial incentives, and working out shared-parking agreements. The most comprehensive review on the subject of TOD examines the roles of not only local-level agencies and governments but also state and federal entities that, as major sources of transit funding, can attach TODfriendly strings to transit dollars and tax policies (16). For example, the Federal Transit Administration considers transit-supportive land use an important criterion for making capital investment funding decisions on "new starts" public transit projects.

The public-sector role is also examined by Porter, who notes that local governments can express support for TOD in general plans, transportation plans, station area plans, special zoning provisions, and transit design guidelines while transit agencies can show support through their mission statements, the publication of design guidelines for TOD, and the adoption of policies and procedures concerning joint development and air rights (3). Cities also can direct economic development to station areas. Lefaver et al. suggest potential actions at all levels of government that would encourage more TOD (34), including additional legislative powers and monetary and policy incentives such as tax credits and environmental exemptions. They also explain how cities including San Jose, San Francisco, Los Angeles, San Diego, and Portland have taken different approaches to promote transit-based development. Each city has used incentives to encourage the private sector to develop within transit corridors and has used existing planning tools available to local governments to implement sound development policy.

With several parties needing to coordinate planning activities to establish TOD, it is often necessary for one entity to take the lead. Several researchers conclude that that entity is the transit agency. Bernick and Cervero note that transit agencies sometimes own land surrounding stations and usually have the most to gain from highquality development, such as increased revenues from leases and higher ridership (10). Transit agencies in many of the places where TOD has been established, such as Los Angeles, Washington, D.C., and Atlanta, Georgia, have specific departments dealing solely with
TOD planning and policy $(33,35)$, thus allowing the agencies to act consistently and expertly on issues of development. The Washington Metropolitan Area Transit Authority, for example, has an Office of Property Development and Management that seeks out developers willing to build TOD on authority-owned land adjacent to stations (36). In Atlanta, the Metropolitan Atlanta Rapid Transit Authority (MARTA) became the nation's first transit agency to partner with a developer when it decided to pursue a mixed-use development for agency-owned lands surrounding its Lindbergh station (37). Even when the transit agency does not own certain parcels of land, it still can take the lead to ensure that TOD principles govern development or redevelopment of those parcels.

\section{Planning for Success}

Several researchers look beyond the details of individual policies or the duties of particular public agencies and instead seek to summarize the general factors that contribute to successful TOD. Niles and Nelson present a list of factors that contribute to successful TOD at station area and regional levels (38). Factors affecting the success of TOD at the station-area level include legible street patterns, pedestrian accommodation (including the presence of sidewalks and convenient walking distances), employment and housing density, and commercial mix. Factors affecting the regional or metropolitan success of TOD include all factors for the stationarea level plus the total number of TODs, transit quality, transit technology, retail siting criteria, regional market structure, consumer activity patterns, travel behavior, zoning flexibility, and housing-type preference. Niles and Nelson (38) and Calthorpe and Fulton (39) are among the few researchers who emphasize the influence of macro-level (or regional) forces and connectivity on individual TODs.

Belzer and Autler present another perspective on the determinants of successful TOD (40). Their six performance areas, designed to measure the performance of an ideal TOD, could easily double as a list of TOD's benefits:

- Location efficiency. Good TODs should provide convenient and efficient transportation links that are blended to reduce auto dependency.

- Value recapture. Transit-rich regions should pay less for transportation (per capita) than auto dependent ones, even after public investments in transit are considered.

- Livability. TODs should lead to improvements in air quality, mobility, and access to services for people of all ages.

- Financial return. Mixed-use strategies should allow for greater flexibility in responding to market cycles.

- Choice. Good TODs should provide a greater number of options for housing, transportation, and lifestyles than standard development.

- Efficiency. Efficient regional land use patterns should reduce land consumption and traffic generation.

Similar principles are found in a TOD guide from the Urban Land Institute (41), which is fairly unique in highlighting the importance of a good parking plan for station areas. Flexible parking standards are emphasized as a means of ensuring that parking volumes are "just right" for the circumstances and needs of individual developments. The guide also suggests four tools to lessen the impact of parking: move it (parking should be a 5- to 7-min walk from the station), share it (coordinate parking needs with surrounding uses), 
deck it (while expensive, it greatly reduces the footprint), and wrap it (provide ground-floor retail).

\section{PREVAILING LOCATIONS}

A review of the literature with an eye trained specifically on TOD locations reveals that, to a large extent, most publicized examples of planned or recently built TOD share a common characteristic: They occur primarily in fast-growing metropolitan areas in the South and on the West Coast. Consequently, in examining case studies of TODs, examples from the outskirts of several areas (San Francisco, Sacramento, San Diego, and Portland as well as Denver, Colorado, and Dallas, Texas) repeatedly appear. Examples of TOD can also be found in high-growth cities like Atlanta, Washington, D.C., and other growing metropolitan areas with extensive rail transit systems. Even though TOD occurs to some degree in these places, it is important to note that TOD is far from being the prevalent form of development.

An often-cited example of TOD on the West Coast is San Diego's Rio Vista West development, a mixture of housing, retail, office space, and public areas located near a transit station. Rio Vista West (which, like many TODs, is planned for development over several phases) ultimately will include more than 1,000 dwelling units, more than 300,000 square feet of retail space, and 165,000 square feet of office space. At its heart will be a mixed-use core containing buildings with ground-floor retail and upper-floor housing $(27,39)$, all centered on a transit station. Mixed-use development also characterizes TOD in Dallas, where development at Legacy Town Center, Addison Circle, and especially the Uptown area focuses on creating 24-hour dense town centers (42). The Uptown neighborhood near downtown Dallas has added 10,000 housing units in the past 5 years and is one of the strongest residential markets in the metropolitan region (43). Similar development trends can be seen in Arlington County, Virginia, near Washington (44).

\section{TOD in Generations Past}

That the current literature does not mention any projects like Rio Vista West or Uptown in older cities of the Northeast and Midwest does not mean that TOD is absent from those places. In fact, TODparticularly pre-1950s TOD-is so prevalent in places with centuryold transit systems like New York, Boston, Massachusetts, and Chicago, Illinois, that TOD there is, as Ohland puts it, "old hat" (45). In this sense, recently built TOD (usually found in "hot" neighborhoods undergoing revitalization) is aimed at reestablishing a functional link between development and transit that adequately balances place and transportation nodes. Clearly, transit stations in older cities are already located in places where they can serve the highest number of residences and workplaces; in these places, spillover development into neighborhoods adjacent to transit stations demonstrates the mutually reinforcing relationship (often taken for granted) between transit service and urban development. Unlike the Sunbelt cities, which saw the majority of their growth occur during automobile-dominated times, development along transit corridors is so customary in older cities that they rarely call it TOD; it's simply regular development. As a result, it can be difficult to find a recent project in those cities that has been actively promoted as transit oriented.

One example of such regular development is 731 Lexington Avenue in midtown Manhattan, which combines a 54-story tower with 900,000 square feet of office space, two floors of retail, and 100 condominiums, all adjacent to the Lexington Avenue/59th Street subway station (46). Another is a proposal by the Enterprise Center, a small business incubator in Philadelphia, to develop 500,000 square feet of office space as well as ground-floor retail along the Market Street transit corridor (47). In Boston, an older city that has explicitly adopted the TOD terminology in its city code and performed extensive research on the most viable locations for TOD to encourage redevelopment (48), numerous transit-oriented projects are lining up on the South Boston waterfront, where the Silver Line uses a busway and bus tunnels (designed for future conversion to light rail) (49-51). The plans and proposals in Boston and other cities provide evidence that TOD is happening along busways in addition to light rail (Portland, Sacramento, and San Diego) and heavy rail (Atlanta, New York, San Francisco, and Washington) systems. In fact, supportive policies for land use are one of the Federal Transit Administration's key innovations in its Bus Rapid Transit (BRT) Initiative (50, 52, 53). Many U.S. BRT projects are modeled on bus transit in Curitiba, Brazil, where a network of local and express buses has encouraged high-density residential districts along key transit corridors (12).

\section{Impediments to Inner-City TOD}

Although it can be difficult to find transit-oriented projects that are actively promoted as TOD in older cities (because TOD is far more common there than in newer, automobile-oriented communities), it is more difficult to find examples from economically distressed inner cities, no matter their location. This discrepancy results from an obvious lack of TOD (or any development, for that matter) in those places, a fact noted by some researchers but directly addressed by only a few. One of those few is Loukaitou-Sideris (54), who surveyed 25 individuals involved in some facet of TOD to understand their impressions of the ingredients needed to successfully establish TOD. Those individuals generally agreed on five major impediments to TOD in inner cities:

- Disinterest of the private sector to locate and invest in the inner city,

- Absence of market demand from the part of the public that can afford to pay the arguably higher cost entailed in a mixed-use development,

- Competitive disadvantage of the inner city,

- Preconceived prejudices regarding inner-city locations, and

- Lack of financing for inner-city locations.

In “There's No There There," Loukaitou-Sideris and Banerjee produce a similar list of missing ingredients that have caused development (and specifically TOD) to lag along the Blue Line through South Central Los Angeles, opened in 1990 (55). Those ingredients include activity near stations, neighborhood amenities, a public sector commitment to development, and a strong local economy. Cervero et al., on the subject of local economic and market conditions, note that transit investments redistribute growth (instead of generating it) and that there must be growth to redistribute for development to occur (16).

That a strong local economy is seen as a key ingredient offers some insight into why the TOD trend is strongest in high-growth metropolitan areas - and why it seems to skip struggling neighborhoods within them (like South Central Los Angeles). It may also offer a clue as to why TOD is largely absent from some older, slowgrowth cities like Buffalo and St. Louis. Like the Blue Line in Los 
Angeles, light rail lines were built in the past 20 to 25 years to traverse economically distressed areas of those cities, and little development (especially TOD) has occurred around them. Considering that the economies surrounding those systems are struggling compared with those of midtown Manhattan and the Boston waterfront, let alone the Sunbelt, the dearth of recent TOD-or any recent development at all-is not surprising. Even in the more economically vital city of Chicago, TOD is occurring in affluent and gentrifying neighborhoods but has been largely absent (along with development in general) from that city's poorer districts (45).

Beyond the issue of local economy, the Los Angeles Blue Lineone of the nation's busiest light rail lines-faces problems from having been situated along an abandoned rail line that traverses vast industrial tracts, where TOD is difficult to implement because residential and commercial densities are low in station areas. The selection of industrial or former freight corridors for new transit facilities often prevents transit routes from connecting key activity centers. The Blue Line thus demonstrates the perils of the subway builder's dilemma, which suggests that in places with density high enough to support rail transit, rail transit is difficult to build because of land assembly, the high expense of construction cost, and the nuisance of construction disruption. Instead of high-density locations, planners often locate transit lines where the projects meet the least resistance, constructing rail transit while lacking a broader vision for land use along a corridor or neighborhood (56). Siting decisions based solely on availability and affordability of land are troublesome for both economic development and transit ridership. Los Angeles' Blue Line has built-in limitations for potential ridership and for land use coordination with access and mobility. Removed from concentrations of residences and jobs, public transit clearly has a diminished role as an economic agent.

Bernick and Cervero explore other impediments to inner-city development, although they focus on barriers formed by the residents of city neighborhoods (10). They offer the example of Atlantic Center in Brooklyn, a development proposed in the late 1980s for the downtown of that New York City borough. The proposal featured high-rise office towers, retail concourses, and hundreds of apartments clustered around a Long Island Rail Road terminal that also served New York City subways and buses. The development never got off the ground, however, because of lawsuits brought by area residents who claimed that the project's density was too high and that it would spur gentrification and the displacement of lowincome households. NIMBY-ism (i.e., opposition to locating an undesirable development in one's neighborhood) of this kind is not uncommon and should be expected in established city (and suburban) neighborhoods (28); hence the subway builder's dilemma.

\section{Close, but Not Quite There}

Babsin et al. present interesting information about TOD in several metropolitan areas not mentioned elsewhere in the literature (30). Their guide for TOD in 21 metropolitan areas contains examples of station area developments in medium-sized, slow-growth cities such as Buffalo; Cleveland, Ohio; and St. Louis, all of which have modern light rail lines running through economically distressed areas. The apparent reason many of the cities Babsin et al. mention do not appear elsewhere in the literature is that many of the projects in those cities do not fully meet the definition for TOD; they really are aborning TODs. For example, Babsin et al. mention a plan to place a Head Start facility near Windermere station in Cleveland, yet the plan has no provision for a dense mix of uses around the Head Start facility or the light rail station (even though area residents are generally supportive of future mixed-use development).

The fact that cities like Cleveland are at least considering TOD and evaluating its promise indicates that the concept is gaining attention in medium-sized, slow-growth cities for its potential to increase transit ridership and revitalize neighborhoods. Nevertheless, many researchers are cautious that transit investments in the United States have fallen short of their objectives where they lack one or more key ingredients, including supportive demographics, employment patterns, land use patterns and densities, and pricing incentives and disincentives (57).

The light rail system in Buffalo is a single, 6-mi line that does not extend into the suburbs. It serves the inner city and has encouraged little development, especially in residential neighborhoods away from downtown, since it began service in 1984. The city has tried to encourage transit- and pedestrian-friendly development along the line through enactment (in 1990) of its Transit Station Area District legislation, which outlines special zoning, design, and parking regulations on properties adjacent to the underground stations (58, chapter 511). In 1994, the city even announced ambitious plans to develop land around LaSalle Station (a station near the city limits with an expansive park-and-ride lot), proposing a midrise tower of offices and apartments above the station (59). However, that plan has never materialized, and the developmentstarved city has permitted several noncomplying developments to occur within station areas, such as the Buffalo-Niagara Medical Campus and the University at Buffalo, South Campus. Nevertheless, the presence of light rail transit stations in Buffalo may have helped stem deterioration and disinvestment in their neighborhoods and suggests that if the light rail line had never been built, some neighborhoods might have deteriorated even more than they have already.

\section{Progress in the Inner City}

One of the few examples of TOD in a struggling inner-city area, and the most cited by far, is the Fruitvale San Francisco Bay Area Rapid Transit (BART) development in Oakland, currently under way. Fruitvale, which has been called the most extensive innercity transit village effort in the United States (11), is planned to contain 500 housing units (mostly above ground-floor retail), an open-air market, a museum and library, open space, and a public plaza. Table 1, which lists the details of selected TOD projects mentioned in this review (including Fruitvale) and some not mentioned, illustrates that TOD in urban centers, either planned or built, represents a wide range of community types. It is difficult to make generalizations about the projects, however, because each TOD creates a mix of housing, retail, office, and other uses that is appropriate to the immediately surrounding community, the transit system, and the metropolitan region. Clearly, the distinct form that TOD takes at each site is also shaped by development obstacles and opportunities that are particular to unique urban environments.

Housing developments associated with TOD can take various forms, from public housing to private housing, and from singlefamily homes at Rio Vista West to second- and third-floor apartments at Fruitvale to high-rise condominiums at 731 Lexington Avenue $(25,28)$. In recent years, the HOPE VI (short for Housing Opportunities for People Everywhere) program administered by the 
TABLE 1 Selected TOD Projects $(8,27,46,47,60-63)$

\begin{tabular}{|l|l|l|l|c|l|l|}
\hline Project & Setting & Status & $\begin{array}{l}\text { Residential } \\
\text { Units }\end{array}$ & $\begin{array}{l}\text { Retail } \\
\text { (sq. ft.) }\end{array}$ & $\begin{array}{l}\text { Office } \\
\text { (sq. ft.) }\end{array}$ & Other \\
\hline Fruitvale, Oakland & $\begin{array}{l}\text { Urban } \\
\text { Infill }\end{array}$ & $\begin{array}{l}\text { Under } \\
\text { Construction }\end{array}$ & 288 & 45,000 & 45,000 & $\begin{array}{l}\text { Health Clinic, Child } \\
\text { Care Facility, Library }\end{array}$ \\
\hline $\begin{array}{l}\text { 731 Lexington Ave., } \\
\text { New York }\end{array}$ & $\begin{array}{l}\text { Urban } \\
\text { Infill }\end{array}$ & $\begin{array}{l}\text { Under } \\
\text { Construction }\end{array}$ & 100 & 157,600 & 900,000 & \\
\hline $\begin{array}{l}\text { The Enterprise } \\
\text { Center, Philadelphia }\end{array}$ & $\begin{array}{l}\text { Urban } \\
\text { Infill }\end{array}$ & Proposed & None & 8,400 & 75,600 & \\
\hline $\begin{array}{l}\text { Pier 4, Boston } \\
\text { Rio Vista West, } \\
\text { San Diego }\end{array}$ & $\begin{array}{l}\text { Urban } \\
\text { Greenfield }\end{array}$ & $\begin{array}{l}\text { Partially } \\
\text { Complete }\end{array}$ & 1,070 & 325,000 & 165,000 & $\begin{array}{l}\text { Community Centers, } \\
\text { Commons, Cinema }\end{array}$ \\
\hline $\begin{array}{l}\text { Hollywood- } \\
\text { Highland, } \\
\text { Los Angeles }\end{array}$ & $\begin{array}{l}\text { Urban } \\
\text { Infill }\end{array}$ & $\begin{array}{l}\text { Proposed } \\
\text { Complete }\end{array}$ & 215 & None & 385,000 & Hotel \\
\hline $\begin{array}{l}\text { Lindbergh Station, } \\
\text { Atlanta }\end{array}$ & $\begin{array}{l}\text { Urban } \\
\text { Greenfield }\end{array}$ & $\begin{array}{l}\text { Partially } \\
\text { Complete }\end{array}$ & 954 & 375,000 & None & $\begin{array}{l}\text { Kodak Theater, } \\
\text { Public Plaza }\end{array}$ \\
\hline
\end{tabular}

U.S. Department of Housing and Urban Development has revitalized public housing projects across the country. Although such housing subsidy programs do not necessarily have transportation components, they do emphasize the creation of mixed-use communities. For example, Centennial Place in Atlanta is a mixture of housing and resident services adjacent to a MARTA station (39).

\section{CONCLUSION}

The literature review has uncovered a great deal of information regarding TOD at suburban and greenfield sites (largely in the western United States) and less information regarding TOD as a tool for urban infill and revitalization, particularly in inner cities. The four key findings follow.

- The literature is consistent and confident in outlining the public policies that support TOD. There is agreement that public-sector entities, led by the transit agency, must share a commitment to encouraging mixed-use, pedestrian-friendly environments around transit stations - a commitment that is made apparent by supportive policies set forth in comprehensive plans, redevelopment plans, transportation plans, and guidelines for parking and design. There is also consensus on what constitutes supportive policies, from tax credits and abatements to flexible parking standards and, most important, to the accommodation of pedestrians, transit users, and bicyclists.

- Most of the literature focuses on TOD at suburban or greenfield sites near cities in the western and southern United States. These sites tend to be growing rapidly, have relatively new transit systems, and be dominated by low-density, automobile-oriented development-a result of those cities having developed mostly in the decades after World War II.

- TOD from the early 20th century is so common in older cities that recently built TODs in those cities often go unpublicized, resulting in a gap in the literature on the subject of contemporary "infill" TOD. Even though infill projects along established transit corridors of older cities likely outnumber the more publicized TOD projects like Rio Vista West in San Diego, the fact that they are usually solitary projects-however mixed their uses-instead of villages probably keeps them below the radar of most observers. The most noted inner-city TOD, Oakland's Fruitvale, is indeed a villagelike development.

- Although very few researchers focus on inner-city TOD, those who do examine the lack of TOD (or any development) near transit lines that traverse economically depressed areas. In such situations, it is generally agreed that the local economic and market conditions are mostly responsible for a dearth of development and that those conditions reinforce (and are reinforced by) negative perceptions of struggling inner cities. Although placing transit lines along a path of least resistance is convenient, it avoids the challenge of connecting existing activity centers and thus lessens the likelihood of significant development in proximity to transit.

TOD in inner-city neighborhoods can be seen as an opportunity with enormous potential. Mixed-use development in the vicinity of transit stations can help transit systems boost ridership and increase revenues from lease arrangements, a situation that could be particularly useful to systems plagued by high operating and maintenance costs and low ridership (2). However, the results of this research suggest that there are significant challenges to developing in built-up areas, and these challenges perhaps explain the slow implementation of TOD in some depressed inner-city areas.

Researchers agree that inner-city TOD perhaps has greater potential for success than suburban or greenfield TOD because of naturally higher concentrations of residences, jobs, and amenities $(10,23)$. However, inner-city sites clearly have more development complications. Researchers also agree that TOD is least likely to succeed in places with few amenities to claim as a locational advantage $(10,23,54,60)$, which further strengthens arguments for urban locations (with higher densities and mixed land use) over suburban locations. Notably, a survey of transit system officials reveals that providing access to employment centers is one of the key objectives of new transit projects (57).

Evaluations of TOD projects that go largely unnoticed in America's older cities and of TOD (or the lack thereof) in economically distressed areas are compelling opportunities for future research. Future research also should examine the link between TOD and neighborhood revitalization in economically distressed areas to help planners and policy makers reap the greatest benefit from new 
and old public transit systems and development potential in their surrounding neighborhoods.

\section{ACKNOWLEDGMENTS}

This research was sponsored by the Niagara Frontier Transportation Authority and supported by a grant from the Federal Transit Administration. The authors thank Susan Herre and Beverly McLean for helpful comments on an early draft.

\section{REFERENCES}

1. Kain, J. Choosing the Wrong Technology: Or How to Spend Billions and Reduce Transit Use. Journal of Advanced Transportation, Vol. 21 1988, pp. 197-213.

2. Pickrell, D. A Desire Named Streetcar: Fantasy and Fact in Rail Transit Planning. Journal of the American Planning Association, Vol. 58, No. 2, 1992, pp. 158-176.

3. Porter, D. TCRP Synthesis of Transit Practice 20: Transit Focused Development. TRB, National Research Council, Washington, D.C., 1997.

4. Porter, D. Transit-Focused Development and Light-Rail Systems: The Lite Connection. In Transportation Research Record 1623, TRB, National Research Council, Washington, D.C., 1998, pp. 165-169.

5. Lowe, M. Shaping Cities. In State of the World (Lester Brown, ed.), Norton, New York, 1992, Chapter 8.

6. Cudahy, B. Cash, Tokens, and Transfers: A History of Urban Mass Transit in North America. Fordham University Press, New York, 2001.

7. Warner, S. Streetcar Suburbs: The Process of Growth in Boston, 1870-1900. Atheneum, New York, 1962.

8. Calthorpe, P. The Next American Metropolis: Ecology, Community, and the American Dream. Princeton Architectural Press, Princeton, N.J., 1993.

9. Audirac, I. Stated Preference for Pedestrian Proximity: An Assessment of New Urbanist Sense of Community. Journal of Planning Education and Research, Vol. 19, No. 1, 1999, pp. 53-66.

10. Bernick, M., and R. Cervero. Transit Villages for the 21st Century. McGraw-Hill, New York, 1997.

11. Bernick, M. Transit Villages: Tools for Revitalizing the Inner City. Access, Vol. 9, 1996, pp. 13-17.

12. Cervero, R. The Transit Metropolis: A Global Inquiry. Island Press, Washington, D.C., 1998.

13. Cervero, R., and M. Bernick. Transit-Centered Urban Villages. In Time-Saver Standards for Urban Design (D. Watson, A. Plattus, and R. Shibley, eds.), McGraw-Hill, New York, 2003, pp. 5.8-1-5.8-10.

14. Belzer, D., and G. Autler. Countering Sprawl with Transit-Oriented Development. Issues in Science and Technology Online, Fall 2002. www.nap.edu/issues/19.1/belzer.htm.

15. Cervero, R., P. Hall, and J. Landis. Transit Joint Development in the United States. Monograph 42. Institute of Urban and Regional Development, University of California, Berkeley, 1992.

16. Cervero, R., C. Ferrell, and S. Murphy. TCRP Research Results Digest 52: Transit-Oriented Development and Joint Development in the United States-A Literature Review. TRB, National Research Council, Washington, D.C., 2002.

17. Joint Development Program. Los Angeles Metropolitan Transportation Authority, Los Angeles, Calif., no date. www.mta.net/trans_planning/ CPD/joint_development/images/program_update.pdf.

18. Arrington, G. B., and T. Parker. Statewide Transit-Oriented Development Study: Factors for Success in California. California Department of Transportation, Sacramento, 2001.

19. Newman, P., and J. Kenworthy. Sustainability and Cities: Overcoming Automobile Dependence. Island Press, Washington, D.C., 1998.

20. Boarnet, M., and N. Compin. Transit-Oriented Development in San Diego County: The Incremental Implementation of a Planning Idea. Journal of the American Planning Association, Vol. 65, No. 1, 1999, pp. 80-95.

21. Giuliano, G. The Weakening Transportation-Land Use Connection. Access, No. 6, 1995, pp. 3-11.

22. Ewing, R., and R. Cervero. Travel and the Built Environment: A Synthesis. In Transportation Research Record: Journal of the Transporta- tion Research Board, No. 1780, TRB, National Research Council, Washington, D.C., 2001, pp. 87-114.

23. Bae, C. Orenco Station, Portland, Oregon: A Successful Transit Oriented Development Experiment? Transportation Quarterly, Vol. 56, No. 3, 2002, pp. 9-18.

24. Cervero, R., and M. Duncan. Transit's Value-Added Effects: Light and Commuter Rail Services and Commercial Land Values. In Transportation Research Record: Journal of the Transportation Research Board, No. 1805, TRB, National Research Council, Washington, D.C., 2002, pp. 8-15.

25. Cervero, R., and M. Duncan. Benefits of Proximity to Rail on Housing Markets. Journal of Public Transportation, Vol. 5, No. 1, 2002, pp. 1-18.

26. Dittmar, H., and G. Ohland. The New Transit Town: Best Practices in Transit-Oriented Development. Island Press, Washington, D.C., 2004.

27. Bragado, N. S. Transit Joint Development in San Diego: Policies and Practices. In Transportation Research Record: Journal of the Transportation Research Board, No. 1669, TRB, National Research Council, Washington, D.C., 1999, pp. 22-29.

28. Cervero, R. Transit Villages in California: Progress, Prospects, and Policy Reforms. Working Paper 98-08. Institute of Urban and Regional Development, University of California, Berkeley, 1998.

29. Nelson, D., J. Niles, and A. Hibshoosh. A New Planning Template for Transit-Oriented Development. MTI Report 01-12. Mineta Transportation Institute, San Jose, Calif., 2001.

30. Babsin, M., M. Hill, L. Melendy, M. O'Neill, and E. Deakin. Real Estate Trends and Transit Oriented Development: A Compendium for 21 Metro Regions. Institute of Urban and Regional Development, University of California, Berkeley, 1997.

31. White, S. M., and J. McDaniel. TCRP Legal Research Digest 12: The Zoning and Real Estate Implications of Transit-Oriented Development. TRB, National Research Council, Washington, D.C., 1999, pp. 1-50.

32. Meck, S. (ed.). Growing Smart Legislative Guidebook: Model Statutes for Planning and the Management of Change. American Planning Association, Chicago, Ill., 2002.

33. Renne, J., and P. Newman. Ideas in Motion: Facilitating the Financing and Development of "Smart Growth." Transportation Quarterly, Vol. 56 , No. 2, 2002, pp. 23-32.

34. Lefaver, S., B. Buys, D. Castillo, S. Mattoon, and J. Vargo. Construction of Transit-Based Development. MTI Report 01-05. Mineta Transportation Institute, San Jose, Calif., 2001

35. Duffy, J. Transit-Oriented Development in Atlanta. Mass Transit, Vol. 28, No. 4, 2002, pp. 20-23.

36. Office of Property Development \& Management. WMATA Joint Development Policies and Guidelines. Washington Metropolitan Area Transit Authority, Washington, D.C., 2002.

37. Chambers, R., and D. Pendered. Transit-Developer Deal a First. The Atlanta Journal and Constitution, Jan. 27, 1999, p. D5

38. Niles, J., and D. Nelson. Measuring Success of Transit-Oriented Development: Retail Market Dynamics and Other Key Determinants. Presented at the American Planning Association Annual Meeting, Seattle, Wash., April 1999.

39. Calthorpe, P., and W. Fulton. Regional City: Planning for the End of Sprawl. Island Press, Washington, D.C., 2001.

40. Belzer, D., and G. Autler. Transit-Oriented Development: Moving from Rhetoric to Reality. Discussion Paper. Brookings Institution Center on Urban and Metropolitan Policy, Washington, D.C., and Great American Station Foundation, Santa Fe, N. Mex., June 2002.

41. Dunphy, R., D. Myerson, and M. Pawlukiewicz. Ten Principles for Successful Development Around Transit. Urban Land Institute, Washington, D.C., 2003.

42. Ohland, G. The Unlikely Success of DART and TOD in Dallas. Progress: Surface Transportation Policy Project, Vol. 12, No. 2, 2002, pp. 6-7.

43. Price Waterhouse Cooper and Lendlease. Emerging Trends in Real Estate 2001. www.lendlease.com.

44. Leach, D. Transit-Oriented Development in Arlington County, Virginia: Thirty Years of Results. Presented at the Congress for New Urbanism XI, Washington, D.C., June 2003.

45. Ohland, G. Transit-Oriented Development in Four Cities. Working Paper. Great American Station Foundation, Santa Fe, N. Mex., 2001.

46. Bagli, C. Bloomberg Is Expected to Close a Deal on Alexander's Site. New York Times, April 27, 2001, p. B8.

47. Brady, T. Enterprise Center Reveals Plan for $\$ 75$ Million Expansion. Philadelphia Inquirer, July 17, 2002 
48. Smallridge, H., D. Kindsvatter, and S. Moran. Boston: A Model for Fostering Transit-Oriented Growth in Dense, Older Cities. In Proc., Commuter Rail/Transit Conference, American Public Transportation Association, Washington, D.C., 2002.

49. Polzin, S., and M. Baltes. Bus Rapid Transit: A Viable Alternative? Journal of Public Transportation, Vol. 5, No. 2, 2002, pp. 47-70.

50. Mass Transit: Bus Rapid Transit Shows Promise. Report to Congressional Requesters. GAO-01-984. U.S. Government Accounting Office, Sept. 2001.

51. Raine, A. Waterfront TOD. Urban Land, May 2003, pp. 79-83.

52. Levinson, H., S. Zimmerman, J. Clinger, and S. Rutherford. Bus Rapid Transit: An Overview. Journal of Public Transportation, Vol. 5, No. 2, 2002, pp. 1-30.

53. Levinson, H., S. Zimmerman, J. Clinger, S. Rutherford, R. L. Smith, J. Cracknell, and R. Soberman. TCRP Report No. 90: Bus Rapid Transit. Volume 1: Case Studies in Bus Rapid Transit. TRB, National Research Council, Washington, D.C., 2003.

54. Loukaitou-Sideris, A. Transit-Oriented Development in the Inner City: A Delphi Survey. Journal of Public Transportation, Vol. 3, No. 2, 2000, pp. 75-98.

55. Loukaitou-Sideris, A., and T. Banerjee. There's No There There. Access, Vol. 9, 1996, pp. 2-6.

56. Loukaitou-Sideris, A., and T. Banerjee. The Blue Line Blues: Why the Vision of Transit Village May Not Materialize Despite Impressive Growth in Ridership. Journal of Urban Design, Vol. 5, No. 2, 2000, pp. 101-125.
57. Deakin, E., C. Ferrell, J. Mason, and J. Thomas. Policies and Practices for Cost-Effective Transit Investments: Recent Experiences in the United States. In Transportation Research Record: Journal of the Transportation Research Board, No. 1799, TRB, National Research Council, Washington, D.C., 2002, pp. 1-9.

58. Charter and Ordinances of the City of Buffalo. City of Buffalo, Buffalo, N.Y., 1993.

59. Fairbanks, P. City Advances Major Project in LaSalle Area, Three Options Include Business Park, Housing. Buffalo News, Nov. 21, 1994 p. A1.

60. Herre, S. 2003. Integration of Transit and Land Use: A Study of Los Angeles Rail Transit Stations. Master's thesis. University of California, Los Angeles, 2003.

61. Palmer, T., Jr. Pier 4 Plan Advances, 3 Towers Tentatively OK'd; Transportation Issues Cited. Boston Globe, Aug. 31, 2002, p. D1.

62. California Transit-Oriented Development (TOD) Searchable Database. California Department of Transportation, Sacramento, 2000 transitorienteddevelopment.dot.ca.gov.

63. MARTA Cuts Ribbon at Lindbergh City Center. American Public Transportation Association, Washington, D.C., Nov. 2002. www.apta.com/ passenger_transport/thisweek/02novemberarch.cfm.

Publication of this paper sponsored by Public Transportation Planning and Development Committee. 